\title{
Establishing AN Association between Risk Tolerance and Behavioral Biases among Indian Investors.
}

\author{
Naela Jamal Rushdi, Sushma
}

\begin{abstract}
Behavioral Finance Literature Has Shown A Mushroom Growth In The Recent Years. Literature Shed Specific Light On How The Concept Evolved And Later Developed To Various Stages Which Helped To Understand Various Market Anomalies And The Psychology of Individuals Through Behavioral Biases. Behavioral Finance Tries To Explain The Logic Behind Applying Of Heuristics Or Shortcuts By Investors To Take Investment Decisions Which Still Need To Be Extensively Studied. The Study Here Attempts For Identify Presence Of Different Biases In Individual Decision Making And Their Association With The Risk Tolerance Capacity. The Results Indicate That Heuristic Biases (I.E. Representativeness Bias, Overconfidence Bias And Gamblers Fallacy Bias) Are Linked To Moderate To High Risk Tolerant Investors. While Herd Bias And Prospect Biases (Loss Aversion Bias And Mental Accounting Bias) Are Found To Be Linked With Low To Moderate Risk Tolerance Levels of Investors. Heuristics Are Positively Correlated With Risk Tolerance However; Prospect And Herd Are Found To Be Negatively Correlated With Risk Tolerance.
\end{abstract}

Keywords, Behavioral Biases, Herd Bias, Heuristics, Prospect, Risk Tolerance.

\section{INTRODUCTION}

From the past 20-30 years, different traditional theories of finance have played an important part in describing the investor decisions [3], [4], [5]. But the major setback came when theories fail to explain irrational behavior of investor, erratic price instabilities and market anomalies. Studies related to investment pattern elucidated that market bubbles were difficult to be understood with the help of standard financial theories. This inspired to the advent of a new field of finance known as behavioral finance, which explicated human psychology, irrationality and biased behavior of investors [8].

Behavioral finance is based on assumption that investor is not always rational in his decision making and they do behave irrationally sometimes [1].

Behavioral finance; also known as psychology of financing is a revolution in the field of finance came in the last 30 years. In 2007 Schindler explored behavioral finance as a coalescing factor of sociology, psychology and finance. Figure 1 below explain the model.

Revised Manuscript Received on December 30, 2019.

* Correspondence Author

Dr. Naela Jamal Rushdi, Director and Professor IILM Academy of Higher Learning, Research Scholar AKTU Lucknow, Uttar Pradesh, India. naela.rushdi@iilmlko.ac.in, sush.87.06@gmail.com

Sushma, Director and Professor IILM Academy of Higher Learning Research Scholar AKTU, Lucknow, Uttar Pradesh, India. naela.rushdi@iilmlko.ac.in, sush.87.06@gmail.com

(C) The Authors. Published by Blue Eyes Intelligence Engineering and Sciences Publication (BEIESP). This is an open access article under the CC BY-NC-ND license (http://creativecommons.org/licenses/by-nc-nd/4.0/)

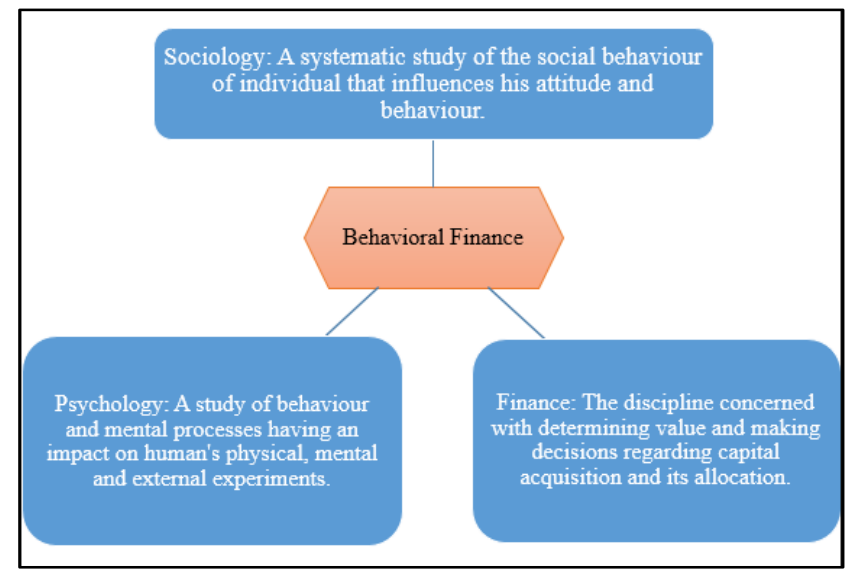

Fig. 1: Behavioral Finance Model (Schindler, 2007)

\section{SYSTEMATIC REVIEW OF LITERATURE}

Neuroscience studies explored that human mind is a complex organ and it is considered as complicated to understand its thought process sometimes. At times people become rational in their decision making but also found to be irrational in many decisions [2].

In the year 1759 a Scottish economist and moral philosopher from Stanford University named Prof. Adam Smith in his work named "Theory of Moral Sentiments" talked about morality and selfishness [22]. He interpreted that people generally take decision for their own benefit. Also, people love to be admired by others and occasionally their decision making is subject to their psychology that whether that decision will be creditable or not. Praiseworthy decision gives them happiness and joy. Hence, they consider this decision as correct decision [23]. "The Wealth of Nations" came as another important work by Adam Smith; first published in 1776. The book is still considered as fundamental work in field of economics [24].

A new series of thoughts came out as "Theory of the Bounded Rationality" given by Herbert Simon in the year 1955. This theory assumes that rationality of individual depends on the cognitive boundaries of their minds. It says that every individual has an upper and lower limit of constraints within which he tries to maximize utility and find an optimal decision [21]. An ice-breaking seminal work in behavioral finance was

done by Israeli psychologists named Daniel Kahneman and Amos Tversky [25]. These two psychologists turned the world of decision science upside down by introducing "Prospect Theory" in the year 1979 [7]. This theory has been the most significant literature in the field of behavioral finance. It explains how individual evaluate gains or losses [26]. 
Establishing AN Association between Risk Tolerance and Behavioral Biases among Indian Investors.

According to prospect theory:

* People sometimes show risk aversion and sometimes risk seeking behavior depending on the nature of the predictions and likelihood of outcomes.

* People try to find out various alternatives (or prospects) they have and rank them on the basis of thumb rule or heuristics [27].

* The theory explained the concept of loss aversion. It says that the preference given to losses is always higher than * the gains for the same amount [28].

In the year 1981 an author named Robert J Shiller in his work named Irrational Exuberance, tried to explain the movements in US stock market by behavioral approach of market participants [20]. He explained the influence of investor's perception in creating the market bubble during late 1990's [19].

In the year 1994 two economists Meir Statman and Shefrin developed a new pricing model called as "Behavioral Asset Pricing Model (BAPM)”. This model categorizes investor into informational traders and the noise traders. Information traders are the rational investors who follow the CAPM model whereas noise traders don't follow the CAPM i.e. traditional financial concepts [16].

Later in the year 2000 they also developed a new portfolio theory, named as the "Behavioral Portfolio Theory (BPT)". The Behavioral Portfolio Theory takes into account the behavioral biases of investors to construct their portfolios in relation with associated risk tolerance [17].

Michael Pompian in his book [13] explored different behavioral biases and categorized them into heuristics and prospect factors. He elucidated the association of these behavioral biases with different risk tolerance levels of the individual investor.

The figure 2 below explains the systematic development in available behavioral finance theories till the starting of $21^{\text {st }}$ century, that contributed a lot in understanding the erratic and irrational behavior of individual investors which later contribute to creation of market bubbles, different anomalies and price fluctuations.

\begin{tabular}{|c|c|}
\hline $\begin{array}{l}\text { Adam } \\
\text { Smith }\end{array}$ & $\begin{array}{l}\text { - Theory of Moral Sentiments } \\
\text { (1759) } \\
\text { - The Wealth of Nations (1776) }\end{array}$ \\
\hline $\begin{array}{l}\text { Herbert } \\
\text { Simon }\end{array}$ & $\begin{array}{l}\text { - Theory of the Bounded } \\
\text { Rationality (1955) }\end{array}$ \\
\hline $\begin{array}{l}\text { Kahnema } \\
\text { n and } \\
\text { Amos }\end{array}$ & - Prospect Theory (1979) \\
\hline $\begin{array}{l}\text { Robert J } \\
\text { Shiller }\end{array}$ & - Irrational Exuberance (1981) \\
\hline $\begin{array}{l}\text { Meir } \\
\text { Statman } \\
\text { and } \\
\text { Shefrin }\end{array}$ & $\begin{array}{l}\text { - Behavioral Asset Pricing } \\
\text { Model (BAPM) (1994) } \\
\text { - Behavioral Portfolio Theory } \\
\text { (BPT) (2000) }\end{array}$ \\
\hline
\end{tabular}

Fig. 2: Development of Behavioral Theories

\section{BEHAVIORAL BIASES}

Hersh Shefrin in the year 2000 talked about various factors associated with psychology of investors, known as behavioral biases. He classified them into heuristic driven and frame dependent biases [18]

* Heuristics are defined as the rules of thumb. It includes overconfidence, anchoring, adjustment, reinforcement learning, excessive optimism and pessimism.

* Frame dependent biases influence people by the way they frame their mindset with the options available. It includes narrow framing, mental accounting and the disposition effect.

Michael M Pompian in the year 2011 also categorized the behavioral biases into two categories named cognitive and emotional biases [13].

* Cognitive biases are deviations from rationality. It includes overconfidence, representativeness, anchoring and adjustment, framing, cognitive dissonance, availability, mental accounting biases.

* Emotional biases are the behavioral pattern affected by a particular emotion that gives them pleasure. It includes endowment bias, loss aversion, optimism, herd behavior and status quo.

\section{RISK TOLERANCE}

Grable and Joo, demarcated risk tolerance as the extreme level of uncertainty that an individual is ready to opt while making any financial decision [8]. Risk tolerance is the level of risk that an individual is ready to accept in selection of various choices during decision making. There have been various scales existing which help in calculation of risk tolerance like SCF scale GL-RTS scale and so on. The study here has used Risk tolerance scale given by Grable and Lytton, which has been found valid and reliable in the year 2015 as well. GL-RTS segments individual into 5 risk tolerant categories given as follows:

1. The score of 18 or below represents Low risk tolerance (i.e. conservative investor).

2. The score of 19 to 22 shows Below-average risk tolerance.

3. The score of 23 to 28 represents Average or moderate risk tolerance.

4. The score of 29 to 32 infers Above-average risk tolerance.

5. The score of 33 and above represents High risk tolerance (i.e. aggressive investor).

\section{RESEARCH OBJECTIVES}

The study attempts to seek the fulfillment of following objectives:

1. To evaluate the presence of behavioural biases among individuals of Uttar Pradesh.

2. To determine the risk tolerance level among individual investors.

3. To examine the association (if any) between behavioral biases and risk tolerance of individual investors. 


\section{RESEARCH METHODOLOGY}

A. Model: Present study consists of two main variables where behavioral biases act as independent variables and risk tolerance as dependent variable. The research model is presented below in figure 3 .

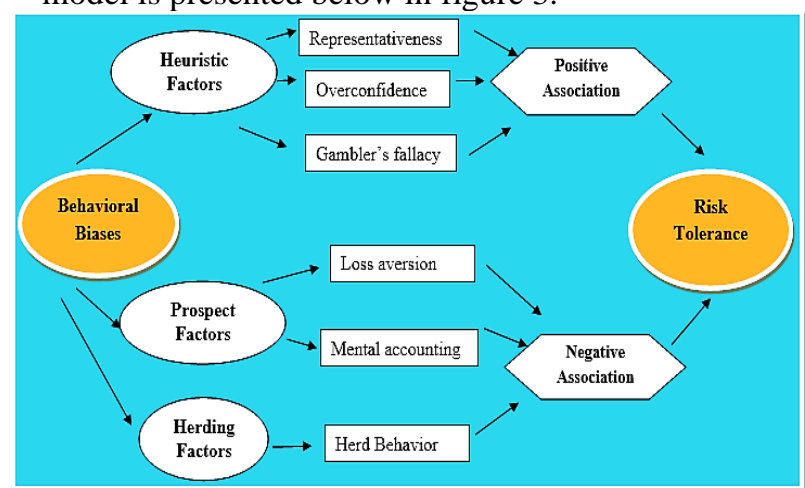

Fig. 3: Research Model

B. Sample Size: The sample here is taken from 487 individual investors from Uttar Pradesh.

C. Calculation of variables:

- The behavioral biases have been calculated with the help of likert based questions where 1 represents strongly disagree and 5 represents strongly agree.

- The risk tolerance has been calculated with the help of 13 item questions based on the scale given by Grable and Lytton.

D. Data Calculation: The data used in the study is primary data, which are collected with the help of structured questionnaire.

E. Research Tools: Different statistical measures have been used for the study are:

- Correlation: To study the relationship between dependent and independent variables, correlation is used.

- Regression: The study here has generated a linear model of fit between dependent and independent variable. This has been done by drawing a linear regression line of association.

- ANOVA test: To test the hypotheses two-way ANOVA test is applied.

F. Hypothesis:

- $\mathrm{H}_{0}$ : There is a no significant association between behavioural biases and risk tolerance.

- $\mathrm{H}_{1}$ : There is a significant association between behavioural biases and risk tolerance.

\section{DATA ANALYSIS AND INTERPRETATION}

A. Descriptive Statistics: The mean, minimum and maximum values with standard deviation of different independent variables are presented in the Table I.

Table I. Descriptive Statistics

\begin{tabular}{|l|l|l|l|l|}
\hline & Min & Max & Mean & $\begin{array}{l}\text { Std. } \\
\text { Dev }\end{array}$ \\
\hline Representativeness & 1 & 5 & 3.18 & 0.69 \\
\hline Overconfidence & 1 & 5 & 2.96 & 1.09 \\
\hline Gamblers_fallacy & 1 & 5 & 2.98 & 0.88 \\
\hline Herd & 1 & 5 & 2.79 & 0.68 \\
\hline Loss_aversion & 1 & 5 & 2.65 & 0.88 \\
\hline Mental_accounting & 1 & 5 & 2.53 & 0.92 \\
\hline
\end{tabular}

\section{B. ANOVA Test: Two-Way ANOVA has been} applied to test following hypothesis.

$\mathrm{H}_{0}$ : There is a no significant association between behavioural biases and risk tolerance.

$\mathrm{H}_{1}$ : There is a significant association between behavioural biases and risk tolerance.

\section{Table II: ANOVA}

\begin{tabular}{|c|c|c|c|c|c|c|}
\hline & Model & $\begin{array}{l}\text { Sum of } \\
\text { Squares }\end{array}$ & Df & $\begin{array}{l}\text { Mean } \\
\text { Square }\end{array}$ & F & Sig. \\
\hline & Regression & 960.428 & 6 & 160.071 & 946.780 & $.000^{b}$ \\
\hline 1 & Residual & 81.153 & 480 & .169 & & \\
\hline & Total & 1041.581 & 486 & & & \\
\hline
\end{tabular}

a. Dependent Variable: risk tolerance code

b. Predictors: (Constant), mental_accounting, Representativeness, herd, loss_aversion gamblers_fallacy, overconfidence

It is evident from the output table II, that the value of $\mathrm{F}$ statistic is significant at $5 \%$ level of significance $(p<0.05)$ This infers that the null hypothesis is not accepted and the alternative one is concluded, which means that there is a significant impact of Behavioral biases and financial risk tolerance.

To measure of strength of association coefficient of determination has been calculated which is denoted by $\mathrm{R}$ square. The table III explains the value of R square, which is 0.922 . This interprets that approximately $92.2 \%$ of the total variance has been explained by the biases considered in this study.

Table III: Model Summary

\begin{tabular}{|c|c|c|c|c|}
\hline Model & $\mathrm{R}$ & $\mathrm{R}$ Square & $\begin{array}{c}\text { Adjusted R } \\
\text { Square }\end{array}$ & $\begin{array}{c}\text { Std. Error of the } \\
\text { Estimate }\end{array}$ \\
\hline 1 & $.960^{\mathrm{a}}$ & .922 & .921 & .411 \\
\hline
\end{tabular}

a. Predictors: (Constant), mental_accounting, Representativeness, herd, loss_aversion, gamblers_fallacy, overconfidence

C. Regression Analysis: Regression analysis is used to test the impact of behavioral biases on risk tolerance of individuals of Uttar Pradesh. It is important to assess whether each of the independent variables included in the model make a significant contribution to the model. This is done by evaluating the model fit and its significance as well. Table IV provides the model fit for the linear model.

Table IV: Coefficients ${ }^{\mathrm{a}}$

\begin{tabular}{|c|c|c|c|c|c|}
\hline \multirow{2}{*}{ Model } & \multicolumn{2}{|c|}{$\begin{array}{c}\text { Unstandardized } \\
\text { Coefficients }\end{array}$} & $\begin{array}{c}\text { Standardized } \\
\text { Coefficients }\end{array}$ & \multirow{2}{*}{ Sig. } \\
\cline { 2 - 4 } & $\mathrm{B}$ & Std. Error & Beta & & \\
\hline (Constant) & 4.190 & .290 & & 14.430 & .000 \\
Representativeness & .183 & .071 & .086 & 2.583 & .010 \\
overconfidence & .224 & .050 & .167 & 4.523 & .000 \\
gamblers_fallacy & .279 & .059 & .168 & 4.723 & .000 \\
Herd & -.085 & .065 & -.039 & -1.301 & .019 \\
loss_aversion & -.626 & .053 & -.377 & -11.823 & .000 \\
mental_accounting & -.319 & .055 & -.201 & -5.816 & .000 \\
\hline a. Dependent Variable: risk tolerance code & & &
\end{tabular}

Table 4 above elucidates the value of unstandardised coefficients (B) that help to generate the linear model between various Behavioral biases (independent variables) and financial risk tolerance (dependent variable). It is also evident from the output table above that the value of $\mathrm{t}$ statistic is significant at $5 \%$ significance level as the value of $\mathrm{p}$ is less than 0.05 (95\% confidence limit). The linear regression equation is as under. 
Establishing AN Association between Risk Tolerance and Behavioral Biases among Indian Investors.

Eq. (1)

Financial risk tolerance $=(4.19)+$

$(0.183) *$ representativeness +

(0.224)*overconfidence +

(0.279)*gamblers_fallacy - $(0.085) *$ herd-

(0.626)*loss_aversion- $(0.319) *$ mental_account

D. Correlation Analysis: Correlation is concerned with describing the strength of relationship between two variables. In this study correlation co-efficient analysis is under taken to find out the relationship between behavioral biases and risk tolerance. Table $\mathrm{V}$ briefly describes the value of Pearson correlation coefficient (r). The relationship between risk tolerance and heuristics biases (representativeness, overconfidence and gamblers fallacy) is found to be positive. The relationship is found to be negative in case of prospect biases (loss aversion, mental accounting) and herding bias in association with risk tolerance.

Table V: Summarized result of correlations coefficients

\begin{tabular}{|c|c|c|}
\hline $\begin{array}{c}\text { Dependent } \\
\text { vaninblo }\end{array}$ & Independent variable & $\begin{array}{c}\text { Correlation } \\
\text { anffininont }\end{array}$ \\
\hline Risk Tolerance & Representativeness & .741 (Positive) \\
\cline { 2 - 3 } & Overconfidence & .797 (Positive) \\
\hline & Gamblers_fallacy & .710 (Positive) \\
\hline & Herd & -.638 (Negative) \\
\hline & Loss_aversion & -.782 (Negative) \\
\hline & Mental_accounting & -.768 (Negative) \\
\hline
\end{tabular}

\section{FINDINGS}

1. As per first objective the study revealed the presence of six behavioral biases namely representativeness, overconfidence, gamblers fallacy, loss aversion, mental accounting and herd bias.

2. According to second objective the individual investors has been categorized into 5 categories. The statistics of these categories is given in table VI below.

Table VI: Tabular presentation of risk tolerance level among investors

\begin{tabular}{|l|l|l|}
\hline risk tolerance code & Frequency(f) & Percentage \\
\hline & & \\
low risk tolerance & 54 & 11.1 \\
below average risk tolerance & 82 & 16.8 \\
moderate risk tolerance & 102 & 20.9 \\
above average risk tolerance & 32 & 6.6 \\
high risk tolerance & 217 & 44.6 \\
Total & 487 & 100 \\
\hline
\end{tabular}

3. The third objective was to find the association between dependent and independent variables. It is found that the 3 biases namely representativeness, overconfidence and gamblers fallacy are found to be positively associated with risk tolerance. The other 3 biases loss aversion, mental accounting and herd bias are found to show negative association with risk tolerance.

\section{CONCLUSION}

Behavioral finance is still evolving and the research done in India is lesser in comparison to that at global level. As behavioral biases are associated to the psychology of human beings therefore the implications are also very wide. Hence, it is going to help a lot to the financial practitioners as well as those seeking a growth in the field of financial advisory. It will definitely help financial advisors to effectively understand the client's psychology and will aid them to develop a behaviorally modified portfolio best suits them. Behavioral finance concepts are going to help investment bankers to understand the market sentiments before going for public issues and will help them to make contingency financial strategists to handle adverse situations.

\section{REFERENCES}

1. Barberis $\mathrm{N}$ and Thaler R, "A Survey of Behavioural Finance", Handbook of the Economics of Finance, Edited by $G$ M Constantinides, M Harris and R Stulz, Elsevier B, University of Chicago, 2003

2. Bentham, J, An Introduction to the Principles of Morals and Legislations, Clarendon Press, Oxford, 1789

3. Bernoulli, D, "Exposition of a New Theory on the Measurement of Risk", Econometrica, vol. 22, no. 1, pp. 23-36, 1954, (Original work published in 1738)

4. Fama E and French, K, "The Cross-Section of Expected Stock Returns", Journal of Finance, vol. 47, no. 2, pp. 427-465, 1992.

5. Fama, E, "Efficient Capital Markets: A Review of Theory and Empirical Work", Journal of Finance, vol. 25, no. 2, pp. 383-417, 1970.

6. Grable J. E. and Joo S.H. "Environmental and bio psychosocial factors associated with financial risk tolerance." Journal of Financial Counselling and Planning, vol. 15, no. 1, pp. 73-82, 2004.

7. Kahneman D and Tversky, A, "Prospect Theory: An Analysis of Decision under Risk”, Econometrica, vol. 47, no. 2, pp. 263-292, 1979

8. Kahneman D, "Bias, Blindness and How We Truly Think", http://www.bloomberg.com/news/bias-blindness-and-how-wetrulythink-part-1-daniel-kahneman.html

9. Lintner, J, "The Valuation of Risk Assets and the Selection of Risky Investments in Stock Portfolios and Capital Budgets", Review of Economics and Statistics, vol. 47, no. 1, pp. 13-37, 1965.

10. Markowitz, HM, "Portfolio Selection”, Journal of Finance, vol. 7, no. 1, pp. 77-91, 1952.

11. Mill JS, Essays on Some Unsettled Questions of Political Economy, Augustus M. Kelley, New York, 1968, (Original work published in 1844)

12. Mossin, J, "Equilibrium in a Capital Asset Market", Econometrica, vol. 34, no. 4, pp. 768-83, 1966

13. Pompian M, Behavioral Finance and Wealth Management: How to Build Optimal Portfolios That Account for Investor Biases, 2nd ed., Wiley Finance Publications, New Jersey, 2011

14. Ross SA, Roll R "An Empirical Investigation of Arbitrage Pricing Theory", Journal of Finance, vol 35, no. 5, pp. 1075-1080, 1980

15. Sharpe, W, "Capital Asset Prices: A Theory of Market Equilibrium under Conditions of Risk", Journal of Finance, vol. 19, no. 3, pp. 425442, 1964.

16. Shefrin H and Statman M, "Behavioral Capital Asset Pricing Theory", Journal of Financial and Quantitative Analysis, vol. 29, no. 3, pp. 323349, 1994

17. Shefrin H and Statman M, 2000, "Behavioral Portfolio Theory", Journal of Financial and Quantitative Analysis, vol. 35, no. 2, pp. 127151, 2011

18. Shefrin H, Beyond Greed and Fear: Understanding Behavioral Finance and Psychology of Investing, Oxford University Press, New York, 2000

19. Shiller RJ, "Do Stock Prices Move too much to be justified by Subsequent Changes in Dividend", American Economic Review, vol. 71, no. 3, pp. 421-436, 1981

20. Shiller RJ, Irrational Exuberance, 2nd Ed., Princeton University Press, Princeton, 2005

21. Simon HA, "A Behavioral Model of Rational Choice", The Quarterly Journal of Economics, vol. 69, no. 1, pp. 99-118, 1955

22. Smith A, The Theory of Moral Sentiments, Printed for A. Millar, in the Strand; and A. Kincaid and J. Bell, in Edinburgh, London 1759

23. Smith A, The Wealth of Nations, W. Strahan and T. Cadell, London 1776

24. Smith, VL, "Rational Choice: The Contrast between Economics and Psychology", Journal of Political Economy, vol. 99, no. 4, pp. 877897, 1991

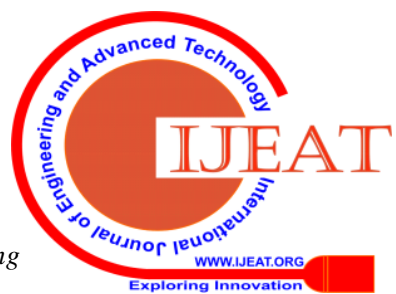


25. Tversky A and Kahneman D, "Advances in Prospect Theory: Cumulative Representation of Uncertainty", Journal of Risk and Uncertainty, vol. 5, no. 4, pp. 297-323, 1992

26. Tversky A and Kahneman D, "Availability: A Heuristic for Judging Frequency and Probability”, Cognitive Psychology, vol. 5, no. 2, pp. 207-232, 1973

27. Tversky A and Kahneman, D, "Judgment under Uncertainty: Heuristics and Biases”, Science, vol. 185, no. 4157, pp. 1124-1131, 1974

28. Tversky, A and Kahneman D, "The framing of decisions and the psychology of choice", Science, vol. 211, no. 4481, pp. 453-458, 1981

29. Von Neumann, J and Morgenstern, O, Theory of Games and Economic Behavior, Princeton University Press, Princeton, 1944

\section{AUTHORS PROFILE}

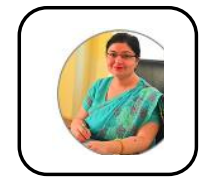

Dr. Naela Rushdi, is a Ph.D. in investment behavior from Lucknow University, an MBA in finance and a CFP from financial planning standards board. She has been teaching finance, accounting and other related subjects to post graduate level management students from past 21 years. Her research work has been published in many national as well as international publications and conferences. She has special interest in the area of investment psychology, behavioral finance and wealth management. Presently she is working as director and professor at IILM Academy of Higher Learning, Lucknow.

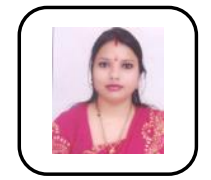

Sushma, has done MBA (finance), AMFI certified, UGC-NET and JRF qualified. She is having teaching experience of more than 6 years at post-graduation level. Presently pursuing Ph.D. from APJ Abdul Kalam Technical University. She is a life member of ASEDS and ICA. She is having more than 10 national and international publications, has been an active participant of various conferences and seminars. Her research area is finance and behavioral economics. 